\title{
The effect of STEM supported research-inquiry-based learning approach on the scientific creativity of 7 th grade students
}

\author{
Merve Gül Kırıcı ${ }^{1}$ and Hasan Bakırcı ${ }^{2}$ \\ ${ }^{1}$ Ministry of Education, Turkey (ORCID: 0000-0001-8959-4770) \\ ${ }^{2}$ Van Yüzüncü Yil University, Faculty of Education, Turkey (ORCID: 0000-0002-7142-5271)
}

\begin{abstract}
This research aims to examine the effect of science, technology, engineering and mathematics (STEM) supported research-inquiry-based learning approach on the scientific creativity of $7^{\text {th }}$ grade students. A pre-test and post-test quasi-experimental design with the control group was adopted into the research. The participants of this research were 64 secondary school students, 35 of whom were in the experimental group and 29 of whom were in the control group. To examine the effect of the intervention, a scientific creativity test was used and Wilcoxon signed ranks test, Mann-Whitney U-test, dependent t-tests were performed to analyse the data. The results revealed a significant difference in scientific creativity test scores, favoring the experimental group. When the subscales originality, flexibility and fluency were analysed, a significant difference in favor of the post-test of the experimental group was noted. However, no significant difference was found between the pre-post test scores of the control group. This means that the intervention has the potential to increase the scientific creativity of seventh grade students. Drawing on the results of this research, we argue that STEM supported education should be used to identify the appropriate steps of the engineering design process for secondary school and high school levels.
\end{abstract}

Keywords: STEM; Research-inquiry-based learning approach; Scientific creativity

Article History: Submitted 11 January 2021; Revised 26 March 2021; Published online 6 April 2021

\section{Introduction}

Science, Technology, Engineering and Mathematics (STEM) is an interdisciplinary educational approach (Bybee, 2010). It aims to motivate students to work collaboratively and conduct experimental studies, learn, research, question, and solve daily problems. Many countries prioritise STEM education in order to achieve economic competitiveness, and to raise qualified individuals who have developed themselves in science, technology, engineering and mathematics (International Technology Education Association [ITEA], 2007; National Research Council [NRC], 2002). STEM approach has an important contribution to individuals' ability to research and question, but also develop their skills of thinking innovatively and creatively.

STEM approach equips students with skills of productivity, strengthens questioning, provides critical and creative thinking, identifies problems encountered in daily life and produces valid

Address of Corresponding Author

Hasan Bakırc1, PhD, Van Yüzüncü Y1l University, Faculty of Education, Department of Science Education, 65090, Van, Turkey.

$\triangle$ hasanbakirci09@gmail.com

How to cite: Kırıc1, M. G. \& Bakırc1, H. (2021). The effect of STEM supported research-inquiry-based learning approach on the scientific creativity of 7th grade students. Journal of Pedagogical Research, 5(2), 19-35. http:// dx.doi.org/10.33902/JPR.2021067921 
solutions, encourages students to take social responsibility and work collaboratively in order to adapt the skills of $21^{\text {st }}$ century (Havice, 2015; Partnership for 21 ${ }^{\text {st }}$ Century Skills, 2009). The Ministry of National Education (MoNE) integrated the STEM approach in 2017 in the Science Curriculum and introduced to secondary school curriculum in 2018. The programme prioritises the skills of problem solving, creative thinking, analytical thinking, innovative thinking, decisionmaking, communication, entrepreneurship and teamwork (MoNE, 2018). STEM approach has significant contributions to the development of students' scientific creativity (Karışan \& Yurdakul, 2017; Siew \& Ambo, 2020). Therefore, this research aims to explore whether STEM supported science teaching has an effect on the scientific creativity of seventh grade secondary school students.

Scientific creativity uses knowledge in order to produce an original product (Hu \& Adey, 2002), and it is a $21^{\text {st }}$ century skill that every student should develop. Therefore, this study links the STEM approach with creativity skills and aims to contribute to the literature by identifying the scientific creativity skill level of seventh grade students. STEM-supported learning environments can also contribute to the development of higher-order thinking skills such as problem solving, critical and creative thinking (Bybee, 2010; Gökbayrak \& Karışan 2017; Samuels \& Seymour, 2015). For example, STEM supported learning environments increase students' curiosity and improve their problem solving and creative thinking skills (Havice, 2015; Samuels \& Seymour, 2015). However, studies examining the effect of STEM approach on scientific creativity are limited. Some of these studies show that the STEM approach is effective on the creativity of secondary school students in science class (Lee \& Lee, 2013), contributes to the scientific creativity of sixth grade students (Basham \& Marino, 2013; Kim, Ko, Han \& Hong, 2014) and improves scientific creativity (Gülhan \& Şahin, 2018). Therefore, this study is important in understanding the effect of STEM supported science teaching on the scientific creativity of middle school seventh grade students.

With the inclusion of the STEM approach in the Science Curriculum in 2018, there is a need to explore the effects of this approach on the high-level thinking skills of students in the learning environment, creativity, entrepreneurship and design skills. At the same time, the Science Curriculum based on research-inquiry-based learning approach (RIBLA) can develop the higher order thinking skills. The use of RIBLA in science teaching has had positive effects on skills of students (Kızılaslan, 2013; Lim, 2001; Sağdıç \& Bakırc1, 2020). The research already shows the positive effects of scientific creativity supported science teaching on the STEM attitudes of seventhgrade students (Sağdıç \& Bakırc1, 2020) and the development of science process skills of secondary school students (Sağdıç, Bakırcı, \& Boynukara, 2019), which makes this study essential. On the other hand, the emphasis on STEM approach makes it essential to understand the effect of using RIBLA in learning environments on students' creative thinking.

The Research Inquiry-Based Learning Approach begins with understanding daily life problems. Students generate questions and design and implement experiments to seek answers to these questions. They can choose a difficult, complicated method or design experiments. Thus, they find out correct information through error-trial method and thus science concepts are brought to a level that they can grasp (Minner, Levy \& Century, 2010; Wood, 2003). The aim of this learning is to raise individuals who research, examine, think meta-cognitively and transfer what they learn to daily life (Pizzolato, Fazio \& Battaglia, 2014). Thus, these skills become a part of the student's knowledge structure (Thier \& Daviss, 2001). High-level thinking skills can be developed with RIBLA because they include different teaching methods and models (Lim, 2001).

There are many studies showing that RIBLA improves students' science literacy (Trna, Trnova \& Sibor, 2012). RIBLA aim is to explore the knowledge in daily life by using the research process and problem solving skills of the student and develop skills and attitudes that can generalize this knowledge (Wilder \& Shuttleworth, 2005). On the other hand, one of the main objectives of the science teaching program is to make students gain science literacy. Given that teaching approaches should serve the purpose of the program, we used RIBLA in this study to focus on students' science literacy skills. 
The literature shows positive outcomes of RIBLA. Some studies display how RIBLA is effective on students' scientific process skills (Keçeci \& Kurbağ-Zengin, 2016). Some argue that using inquiry-based science teaching in classrooms, help students to better grasp concepts such as basic facts, concepts, principles, laws and theories, and this creates a positive attitude towards science and provides students with adequate understanding about the nature of science (Chippetta \& Adams, 2004; Kara \& Şahin, 2019). The use of this approach also increases the academic achievement of students, improves their scientific process skills and attitudes towards science and technology (Çelik \& Çavaş, 2012; Kara, 2018; Wilder \& Shuttleworth, 2005). RIBLA-supported laboratory activities play an important role in the development of students' scientific process skills (Kizilaslan, 2013).

The research on STEM approach differs according to the education level (Bakırc1 \& Kutlu, 2018). Most STEM studies are conducted with secondary school students (Dumanoğlu, 2018; Gazibeyoğlu, 2018; Pekbay, 2017; Yamak, Bulut \& Dündar, 2014) and very few studies are conducted with primary and pre-school students (Koyunlu-Ünlü \& Dere, 2018). Although studies conducted with primary school students have increased in the last five years, they are still limited in numbers (Şahin, Ayar \& Adıgüzel, 2014). STEM approach research usually explores students' interests (Pekbay, 2017), student perceptions (Gülhan \& Şahin, 2018), attitudes (Gazibeyoğlu, 2018; Gülhan \& Şahin, 2018; Yasak, 2017), skills and student knowledge (Pekbay, 2017). The research is mostly focused on the academic achievements and knowledge of the students. Therefore, this research will focus on the scientific creativity of secondary school students in STEM supported science education.

The Force and Energy unit in the Science Curriculum includes both difficult and multiple disciplines at secondary school level (Yürümezoğlu, Ayaz \& Çökelez, 2009). In addition, one of the most important concepts that students have difficulty in constructing is the concept of Energy (Stylianidou, Ormerod \& Ogborn, 2002). Several studies show that that students misconfigure kinetic energy and potential energy types (Taşdemir \& Demirbaş, 2010). The insufficient understanding of the concepts in the unit of "Force and Energy" by the students and their misconceptions show that this unit includes abstract concepts and the methods and techniques applied so far are insufficient (Demir \& Çökelez, 2012). Therefore, in this study, STEM activities related to "Force and Energy" unit were developed and applied within the scope of RIBLA. Thus, the research aims to minimize these problems experienced by students in the teaching process.

The limited number of research on STEM-supported RIBLA (Bakırc1 \& Kutlu, 2018; Günbatar \& Bakırc1 2019), and the lack of studies showing the use of STEM-supported RIBLA in the teaching of the "Force and Energy" unit make this research necessary. In addition, the STEM approach plays an important role in the economic competitiveness of countries, raising qualified individuals with $21^{\text {st }}$ century skills and developing high-level thinking skills (Bybee, 2010; Havice, 2015). Studies on STEM approach have a particular focus on academic achievement and attitude, and the fact that Science Curriculum includes STEM approach makes this study important. The research poses the following question "Does STEM supported RIBLA have an effect on the scientific creativity of seventh grade students?" We seek responses to the following questions:

1. Is there a statistically significant difference between the total scores of the experimental and control groups in the Scientific Creativity Test (SCT)'s pre and post-test?

2. Is there a statistically significant difference between the pre-test and post-test scores of the SCT's originality sub-scale of the experimental and control groups?

3 . Is there a statistically significant difference between the post-test scores of the originality subscale of the SCT of the experimental and control groups?

4. Is there a statistically significant difference between the pre-test and post-test scores of the flexibility sub-scale of the SCT of the experimental and control groups?

5. Is there a statistically significant difference between the post-test scores of the flexibility subscale of the SCT of the experimental and control groups?

6. Is there a statistically significant difference between the pre-test and post-test scores of the 
fluency sub-scale of the SCT of the experimental and control groups?

7. Is there a statistically significant difference between the post-test scores of the fluency subscale of the SCT of the experimental and control groups?

\section{Method}

\subsection{Research Design}

This research uses a quasi-experimental model with a pre-test - post-test control group to identify the effect of STEM supported RIBLA on the scientific creativity of $7^{\text {th }}$ grade students. Groups were determined by unbiased assignment. Pre and post application data collection tools were applied to both groups (Karasar, 2003). If there was no significant difference between the pre-test results of the groups, the groups were considered equivalent. Pre and post test scores are compared in order to test whether the applications in the control and experimental groups are effective (Christensen, 2004). So, quasi-experimental design was used in this study and presented in Table 1.

Table 1

Methods used in the research

\begin{tabular}{lclc}
\hline Group & Pre-Test & Duration of Implementation & Post-Test \\
\hline Experiment & SCT & RIBLA based worksheets, STEM activities & SCT \\
Control & SCT & RIBLA based worksheets & SCT \\
\hline
\end{tabular}

SCT: Scientific Creativity Test

\subsection{Participants}

The research was carried out with a total of 64 students, 35 of whom were in the experimental group and 29 of them were in the control group, in a secondary school in the Eastern Anatolia Region during the 2018-2019 academic year. One of the researchers was working at a school where the study was conducted, therefore, we preferred convenient sampling as it yielded to be the most practical method in terms of the economic costs, the speed and practicality of the research (Patton, 2005). When the sampling size does not allow for generalisation, the researchers usually consider the most effective way of conducting a study (Vogt, Gardner \& Haeffele, 2012).

\subsection{Data Collection Tool}

We used a Scientific Creativity Test (SCT) as a pre-test and post-test. SCT was developed by Hu \& Adey (2002). The researchers also prepared five scientific creativity questions in parallel with the 'Force and Energy' unit. The first question was taken from the Turkish adaptation of Hu \& Adey (2002). Nine questions were initially developed and shared with two lecturers and two Turkish teachers to get their input. Following their feedback, the number of questions was reduced to six.

The pilot study of SCT was conducted with 80 students. The total scores of the six items were calculated and the Cronbach Alpha internal consistency coefficient of the scale was calculated as 0.95. A positive and high correlation indicates that there are questions with similar characteristics. In this case, the internal consistency of the test is high (Büyüköztürk, 2011). Table 2 presents the correlation coefficients between the total scores of the scale and the scores of each item.

Table 2

The total correlation of scientific creativity items

\begin{tabular}{lllllll}
\hline & 1st question & 2nd question & 3rd question & 4th question & 5th question & 6th question \\
\hline Total & .86 & .92 & .95 & .79 & .87 & .67 \\
\hline
\end{tabular}

$* * p<.01$

The correlation between $0.81-1$ represents very strong, $0.60-0.80$ indicates strong, $0.40-0.59$ is medium, 0.20-0.39 can be considered low whereas the correlation below 0.20 is weak (Büyüköztürk, 2011). The item-total correlations of scientific creativity questions shows that item 1 , 
item 2, item 3, and item 5 had a very strong correlation, while item 4 and item 6 had a strong level of correlation.

A t-test was conducted for the significance of the difference between the scores of the upper $27 \%$ and lower $27 \%$ groups of the scientific creativity scale items in order to examine whether they can distinguish students. The analysis is presented in Table 3.

Table 3

T-test results of scientific creativity questions according to the lower upper groups

\begin{tabular}{llllllcc}
\hline Question & & $N$ & Mean & $S D$ & $d f$ & $t$ & $p$ \\
\hline \multirow{2}{*}{ Item 1 } & Upper Group & 22 & 5.5000 & 1.71131 & 21 & 6.940 & .000 \\
& Lower Group & 22 & 2.4545 & 1.14340 & 21 & & \\
\hline \multirow{2}{*}{ Item 2 } & Upper Group & 22 & 6.0455 & 1.39650 & 21 & 9.837 & .000 \\
& Lower Group & 22 & 1.9545 & 1.36198 & 21 & & \\
\multirow{2}{*}{ Item 3 } & Upper Group & 22 & 6.9091 & 0.86790 & 21 & 18.897 & .000 \\
& Lower Group & 22 & 1.4091 & 1.05375 & 21 & & \\
\multirow{2}{*}{ Item 4 } & Upper Group & 22 & 5.8636 & 2.81654 & 21 & \multirow{2}{*}{6.090} & .000 \\
& Lower Group & 22 & 1.8182 & 1.33225 & 21 & & \\
\hline \multirow{2}{*}{ Item 5 } & Upper Group & 22 & 4.1818 & 1.43548 & 21 & 7.638 & .000 \\
& Lower Group & 22 & 1.2273 & 1.10978 & 21 & & \\
\hline \multirow{2}{*}{ Item 6 } & Upper Group & 22 & 9.1364 & 3.52265 & 21 & 5.589 & .000 \\
& Lower Group & 22 & 3.8636 & 2.67787 & 21 & & \\
\hline
\end{tabular}

When Table 3 is examined, all items of scientific creativity differ significantly according to the lower $27 \%$ group and the upper $27 \%$ group. The significant relationship between the groups can be evaluated as an indicator of the internal consistency of the test (Büyüköztürk, 2011).

\subsection{Data Analysis}

Explanations were provided on how to analyze the data from the pre-test and post-test. The results of the normality analysis performed with the skewness-kurtosis coefficients and KolmogorovSimirnov (K-S) test was calculated. Statistical values of the SCT pre-test and post-test averages in the experimental and control groups are given in Table 4.

Table 4

Experimental and control group SCT pre-test and post-test descriptive statistics values

\begin{tabular}{lllcccccc}
\hline Groups & Tests & $N$ & Min & Mean & SD & Variance & Skeweens & Kurtosis \\
\hline \multirow{2}{*}{ Experiment } & Pre-test & 29 & 10 & 18.93 & 5.57 & 30.99 & .392 & -.074 \\
& Post-test & 29 & 27 & 32.79 & 3.17 & 10.03 & .102 & -.406 \\
\hline Control & Pre-test & 35 & 8 & 17.91 & 5.58 & 31.08 & -.027 & -.339 \\
& Post-test & 35 & 11 & 19.26 & 4.85 & 23.50 & .803 & .163 \\
\hline
\end{tabular}

Table 4 shows that the skewness and kurtosis values of the pre-test and post-test score distributions of the experimental and control groups remained within the normal distribution limits $(+2,-2)$. The results of the normality test are given in Table 5 to provide detailed information about the normality of the distribution of data.

Kolmogorov-Simirnov values in Table 5 show that the pre-test and post-test scores of the experimental group and the control group were normally distributed $(p<0.05)$. However, when Shapiro-Wilk values were examined, the control group did not show a normal distribution in the post-test. SCT pre-test scores showed a normal distribution, while the post-test average scores did not display a normal distribution. In addition, when the homogeneity (levene) test results were 
Table 5

Experimental and control group SCT pre-test and post test normality analysis results

\begin{tabular}{llcccccc}
\hline Groups & Tests & \multicolumn{2}{c}{ Kolmogorov- Simirnov } & \multicolumn{3}{c}{ Shapiro- Wilk } \\
\hline \multirow{2}{*}{ Experiment } & Statistics & SD & $\mathrm{p}$ & Statistics & SD & $\mathrm{p}$ \\
& Pre-test & 0.084 & 29 & 0.200 & 0.971 & 29 & 0.597 \\
& Post-test & 0.116 & 29 & $0.200^{*}$ & 0.971 & 29 & 0.575 \\
\hline Control & Pre-test & 0.111 & 35 & 0.200 & 0.967 & 35 & 0.364 \\
& Post-test & 0.136 & 35 & 0.097 & 0.933 & 35 & 0.035 \\
\hline
\end{tabular}

$(p<0.05)$

analyzed, the experimental and control groups showed homogeneous distribution in their pretests $(p(0.756)>0.05)$, but they did not show homogeneous distribution in their post-tests $(p(0.036)<0.05)$. Therefore, while comparing the pre-test results of the experimental and control groups, the independent groups t-test was performed and the Mann Whitney U-test was used for the post-test comparison. The dependent groups t-test was applied in the comparison of the SCT experimental group pre-test and post-test, the Wilcoxon Signed-Ranks Test was used for the control group as pre-test and post-test did not show normal distribution.

The skewness-kurtosis coefficients of the originality subscale of the scientific creativity test and the normality analysis results performed with the Kolmogorov-Simirnov (K-S) test was calculated, and the statistical values are presented in Table 6.

Table 6

Experiment and control group SCT originality sub-dimension pre-test and post-test statistics values

\begin{tabular}{lllcccccc}
\hline Groups & Tests & $N$ & Min & Mean & SD & Variance & Skewness & Kurtosis \\
\hline Experiment & Pre-test & 29 & 2,0 & 5.72 & 2.75 & 7.56 & .719 & .369 \\
& Post-test & 29 & 4,0 & 8.45 & 2.31 & 5.33 & .324 & -.219 \\
\hline Control & Pre-test & 35 & 1,0 & 4.49 & 2.77 & 7.67 & 1.091 & .799 \\
& Post-test & 35 & 1,0 & 4.51 & 2.45 & 6.02 & .615 & -.339 \\
\hline
\end{tabular}

Table 6 shows that the skewness and kurtosis values of the SCT originality sub-scale pre-test and post-test score distributions of the experimental and control groups remained within the normal distribution limits $(+2,-2)$. In order to provide more information about the normality of the distribution of data, the results of the normality test were examined. When Kolmogorov-Simirnov and Shapiro-Wilk values indicated that the experimental group's pre-test (.095) and post-test (.191) scores were normally distributed, but the control group's pre-test (.003) and post-test (.034) scores were not normally distributed. Nonparametric Mann Whitney U-Test was applied to the experimental-control groups for pre-test and post-test comparisons in the SCT originality subscale. In addition, dependent groups t-test was used to compare experimental group pre-test-post-test data, and Wilcoxon signed-ranks test was used for comparison of control group pre-test-post-test data.

\subsection{Process}

The research lasted six weeks (4 hours per week, 24 hours of teaching). The students in both experimental and control groups were provided with worksheets (prepared in parallel with the MEB textbook) prepared by the researcher according to the RIBLA. In addition, experimental group received STEM activities prepared by the researcher. The researcher prepared both the teacher STEM Activity Plan and the student worksheet based on STEM activities. A total six STEM activities were developed in the context of the Force and Energy unit. One STEM activity was carried out every week in the experimental group. At the end of the study, Scientific Creativity Test was applied as a pre-and post-test to see the effect of STEM supported RIBLA on students' 
scientific creativity. One of the STEM activities developed by the researchers in the study was given as an example in Appendix 1.

\section{Findings}

In this section firstly, the findings from the pre and post test scores of the SCT were given. Then, findings related to the sub-dimensions of the SCT, originality, flexibility and fluency dimensions were presented. The comparison of the pre-test scores of the SCT of the experimental and control groups with the independent $\mathrm{t}$-test was given in Table 7.

Table 7

Independent T-test results for the significance between the SCT pre-test scores of the control and experimental groups

\begin{tabular}{lccccc}
\hline Groups & $N$ & $\bar{X}$ & $S D$ & $t$ & $p$ \\
\hline Experiment & 29 & 18.93 & 28 & 0.727 & 0.470 \\
Control & 35 & 17.91 & 34 & & \\
\hline
\end{tabular}

$(p<0.05)$

According to the results given in Table 7, the average score of the experimental group from the pre-test was 18.93, and the control group score was 17.91. According to the results in the t-test analysis for unrelated groups, there was no significant difference between the experimental and control groups' response levels to SCT. Mann Whitney U-Test results between the post-test scores of the Scientific Creativity Test (SCT) of the experimental and control groups are given in Table 8 $[t(62)=0.727, p>.05]$.

Mann Whitney U-Test results between the post-test scores of the SCT of the experimental and control groups are given in Table 8 .

Table 8

SCT post-test Mann Whitney U-Test results of experimental and control groups

\begin{tabular}{lccccc} 
Groups & $\boldsymbol{N}$ & Rank Mean & Rank Total & $\boldsymbol{U}$ & $p$ \\
\hline Experiment & 29 & 49.40 & 1432.50 & 17.50 & .000 \\
Control & 35 & 18.50 & 647.50 & & \\
\hline$(p<0.05)$ & & & &
\end{tabular}

In Table 8, the average rank of the experimental group after the implementation is 49.40 , and the average of the control group is 18.50. According to the Mann Whitney U-test analysis results, a significant difference was found in favor of the experimental group between the post-test scores of the experimental and control groups $[U=17.50 ; p<0.05]$.

The Wilcoxon Signed Ranks Test results of the pre and post-test total scores of the experimental and control groups are presented in Table 9.

Table 9

Wilcoxon Signed Rank Test results of pre and post test scores of experimental and control groups

\begin{tabular}{llcccccc}
\hline Groups & Tests & & $N$ & Rank Mean & Rank Total & $z$ & $p$ \\
\hline Experiment & Post-test & Negative Rank & 0 & 0.00 & 0.00 & 4.71 & .000 \\
& Pre-test & Positive Rank & 29 & 15.00 & 435.00 & & \\
& & Equal & 0 & - & - & & \\
\hline Control & Post-test & Negative Rank & 12 & 12.29 & 147.50 & 1.52 & .129 \\
& Pre-test & Positive Rank & 17 & 16.91 & 287.50 & & \\
& & Equal & 6 & - & & & \\
\hline
\end{tabular}

*Based on negative ranks

Table 9 shows that a significant difference between the experimental group students' pre and post test scores $[z=4.71, p<.05]$. Considering the mean rank and rank total of the difference 
scores, this observed difference is in favor of the post-test score. There was also no significant difference between the pre and post test scores of the control group students $[z=-5.36, p<.05]$.

\subsection{Findings Regarding Originality Sub-Scale of SCT}

Mann-Whitney U-Test results of the pre and post-test total scores of the originality sub-scale of the experimental and control groups are given in Table 10.

Table 10

Mann Whitney U-Test results between pre-test and post-test scores of the originality sub-scale of the experiment and control groups

\begin{tabular}{lllllcc}
\hline Test & Groups & $N$ & Rank Mean & Rank Total & $U$ & $p$ \\
\hline Pre-test & Experiment & 29 & 37.45 & 1086.00 & \multirow{2}{*}{364.000} & \multirow{2}{*}{051} \\
& Control & 35 & 28.40 & 994.00 & & \\
\hline \multirow{2}{*}{ Post-test } & Experiment & 29 & 45.69 & 1325.00 & \multirow{2}{*}{125.000} & \multirow{2}{*}{000} \\
& Control & 35 & 21.57 & 755.00 & \\
\hline
\end{tabular}

$(\mathrm{p}<0.05)$

Table 10 shows no significant difference between the pre-test scores of the originality sub-scale of the experimental and control groups before the application $[U=364.000, p>.05]$. After the implementation, there is a significant difference in favor of the experimental group between the post-test scores of the originality sub-scale of the experimental and control groups $[U=125.000$, $p<.05]$.

The results of the Wilcoxon Signed Ranks Test of the pre and post-test total scores of originality sub-scale of the experimental and control groups are presented in Table 11.

Table 11

Results of the Wilcoxon Signed Ranks Test between pre and post test scores of the originality sub-scale of the experimental and control groups

\begin{tabular}{lcccccc}
\hline \multirow{2}{*}{ Groups } & $\begin{array}{c}\text { Pre-test } \\
\text { Post-test }\end{array}$ & $N$ & Rank Mean & Rank Total & $z$ & $p$ \\
\hline \multirow{2}{*}{ Experiment } & Negative Rank & 1 & 12.50 & 12.50 & 4.16 & 0.000 \\
& Positive Rank & 25 & 13.54 & 338.50 & & \\
& Equal & 3 & & & & \\
\hline \multirow{3}{*}{ Control } & Negative Rank & 14 & 14.82 & 207.50 & 0.22 & 0.827 \\
& Positive Rank & 15 & 15.17 & 227.50 & & \\
& Equal & 6 & & & & \\
\hline
\end{tabular}

*Based on the negative ranks

Table 11 shows a significant difference between the pre and post test scores of the SCT's originality sub-dimension of the experimental group students $[z=4.16, p<.01]$. Considering the mean rank and rank total of the difference scores, the observed difference is in favor of the posttest score. Table 11 shows no significant difference between the pre and post test scores of the SCT's originality sub-scale of the control group students $[z=0.22, p>.05]$.

\subsection{Findings Regarding Flexibility Sub-Scale of SCT}

Mann Whitney U-Test results between the pre-test and post-tests of the experimental and control groups are presented in Table 12. 
Table 12

Mann Whitney U-Test results between pre-test and post-test scores of flexibility dimension of between of experiment and control groups

\begin{tabular}{lllcccc}
\hline Test & Group & $N$ & Rank Mean & Rank Total & $U$ & $p$ \\
\hline Pre-test & Experiment & 29 & 30.83 & 894.00 & 459.00 & .507 \\
& Control & 35 & 33.89 & 1186.00 & & \\
\hline Post-test & Experiment & 29 & 47.57 & 1379.50 & 70.50 & .000 \\
& Control & 35 & 20.01 & 700.50 & & \\
\hline
\end{tabular}

Table 12 shows no significant difference between the pre-test scores of the flexibility sub-scale of the experimental and control groups before the implementation $[U=459.00, p>.05]$. Mean ranks also indicate that there is no significant difference between the pre-test scores of the groups. After the implementation, there is a significant difference in favor of the experimental group between the post-test scores of the experimental and control groups $[U=70.50, p<.05]$. The posttest scores of the students in the experimental group are higher than the post-test scores of the students in the control group.

The results of the Wilcoxon Signed Ranks Test of the pre and post-test total scores of the flexibility sub-scale of the experimental and control groups are presented in Table 13.

Table 13

Wilcoxon Signed Ranks Test results of the experimental and control groups' comparison of pre and post test scores of flexibility sub-scale

\begin{tabular}{cccccccc}
\hline Group & Tests & $N$ & Rank Mean & Rank Total & $z$ & $p$ \\
\hline Experiment & Post-test & Negative Rank & 0 & 0.00 & 0.00 & 4.72 & .000 \\
& Pre-test & Positive Rank & 29 & 15.00 & 435.00 & & \\
& & Equal & 0 & - & - & & \\
\hline \multirow{2}{*}{ Control } & Post-test & Negative Rank & 8 & 11.38 & 91.00 & 1.94 & .052 \\
& Pre-test & Positive Rank & 17 & 13.76 & 234.00 & & \\
& & Equal & 10 & - & & & \\
\hline
\end{tabular}

${ }^{*}$ Based on Negative Rank.

Table 13 shows a significant difference between the scores of the experimental group students in the pre and post-test of the flexibility subscale $[z=4.72, p<.01]$. When the mean rank and rank total of the difference scores are taken into consideration, this difference is in favor of the post-test score. There is no significant difference between the scores of the control group students in the pre and post-test of the flexibility subscale $[z=1.94, p>.05]$.

\subsection{Findings Regarding Fluency Sub-Scale of SCT}

Mann Whitney U-Test results between the pre-test and post-test scores of the fluency sub-scale of the experimental and control groups are presented in Table 14.

Table 14

Mann Whitney U-Test Results between pre-test and post-test scores of the experimental and control groups of fluency sub-scale

\begin{tabular}{lllcccc}
\hline Test & Group & $N$ & Rank Mean & Rank Total & $U$ & $p$ \\
\hline Pre-test & Experiment & 29 & 30.71 & 890.50 & 455.50 & .477 \\
& Control & 35 & 33.99 & 1189.50 & & \\
\hline Post-test & Experiment & 29 & 49.98 & 1449.50 & 0.500 & .000 \\
& Control & 35 & 18.01 & 630.50 & & \\
\hline
\end{tabular}

Table 14 shows no significant difference between the pre-test scores of the fluency sub-scale of the experimental and control groups before the implementation $[U=455.50, p>.05]$. Rank mean 
shows no significant difference between the pre-test scores of the groups. It shows that there is a significant difference in favor of the experimental group between the post-test scores of the fluency sub-scale of the experimental and control groups after the application $[U=0.500, p<.05]$. Also, the post-test scores of the students in the experimental group are higher than the post-test scores of the students in the control group.

The results of the Wilcoxon - Signed Ranks Test of the pre and post test total scores of the fluency sub-scale of the experimental and control groups are presented in Table 15.

Table 15

Wilcoxon Signed Rank Test results in paired comparison of the experimental and control groups' pre and post test scores of the fluency sub-scale

\begin{tabular}{lccccccc}
\hline Group & Tests & $N$ & Rank Mean & Rank Total & $z$ & $p$ \\
\hline Experiment & Post-test & Negative Rank & 0 & 0.00 & 0.00 & 4.71 & .000 \\
& Pre-test & Positive Rank & 29 & 15.00 & 435.00 & & \\
& & Equal & 0 & - & - & &
\end{tabular}

\begin{tabular}{lccccccc}
\hline Control & Post-test & Negative Rank & 8 & 10.19 & 81.50 & 1.20 & .228 \\
& Pre-test & Positive Rank & 13 & 11.50 & 149.50 & & \\
& & Equal & 14 & - & & & \\
& & &
\end{tabular}

*Based on the negative rank

Table 15 shows a significant difference between the scores of the experimental group students in the pre and post test of the fluency sub-scale $[z=4.71, p<.01]$. When the mean rank and rank total of the difference scores are taken into consideration, this observed difference is in favor of the post-test score. It is observed that there is no significant difference between the pre and post test scores of the fluency sub-scale of the control group students $[z=1.20, p>.05]$.

\section{Discussion and Conclusion}

The research shows that there is no significant difference between the pre-test scores of the SCT of the experimental and control groups (Table 7). This finding indicates that the scientific creativity levels of the experimental and control groups' students were close or equivalent before the implementation, and it also echoes the findings in the literature. If the measured characteristics of the students are equal or close before any experiment or intervention, this means that there is a clear understanding of the change with the experiment. The findings display that there is a significant difference between the SCT post-test scores of the experimental and control groups, and this difference is in favour of the experimental group (Table 8). There is also a statistically important difference between the pre-test and post-test SCT of the experimental group in favour of the post-test. On the other hand, there is no statistically significant difference between the pre-test and post-test SCT of the control group (Table 9). The main reason for these findings may be related to using STEM activities with the experimental group students. The experimental group students were asked to engage with a problem and come up with a solution. They also collectively decided the design, prototype and equipment. This may have increased their SCT mean by 19 points compared to the other group. They also developed their scientific creativity as they created original structures (Genek \& Küçük, 2020; Ryu \& Lee, 2013).

Experimental group students increased their "originality", "flexibility" and "fluency" scores in comparison to the control group, because their responses were more functional than the control group. In the $5^{\text {th }}$ question of SCT post-test, the following instruction was given: "If you were given two types of napkins, how would you test which was better to do this, please write down all the methods you can think of, the tools you will use, and simply explain how you will follow." The experimental group students answered this question by using dependent, independent and control variables in terms of scientific process skills. The experimental group students identified and 
expressed the experimental processes in the original designs they built. In other words, they designed an experimental setup to solve the problem. The use of STEM activities with the experimental group students for six weeks encouraged them to think creatively to find solutions to the problems (Genek \& Küçük, 2020). They brainstormed with discussions and learned to look at problems from different perspectives. While establishing the prototype, they checked whether it worked according to the purpose, questioned the reason when there was a problem, therefore these attitudes provided much higher SCT mean scores than the control group. In fact, students broadened their perceptions by paying attention to the dimensions of durability, cost and aesthetics like an engineer, which increased their mean scores in the test (Jin-Ho et al. 2014; Tunç \& Bağceci, 2021).

In the control group, the materials to be used in the worksheets were prepared in parallel with the Ministry of National Education textbook, therefore it prevented students from making unique designs. In addition, their SCT mean scores did not increase because the control group students were not evaluated in different dimensions (in terms of strength, cost and aesthetics) as in the experimental group students and they did not produce a product that would require knowledge exchange. Also, there was not a significant increase between pre-test and post-test SCT averages of control group since the model was functionally seamless and students did not need to show any effort to develop products (Ceylan, 2014; Dong-Ju, Jin-Ho \& Su-Hong, 2016).

Originality, flexibility and fluency sub-scales of SCT were statistically analyzed. The findings shows that there is no significant difference between the experimental-control groups pre-test scores in the originality subscale, but there is a significant difference in favour of the experimental group between the post-test scores of the experimental-control groups (Table 10). There is also a statistically significant difference between the scores of the experimental group's pre-test and posttest originality sub-scale in favour of the post-test (Table 11). There is no statistically significant difference between the scores of the control group for the pre-test and post-test originality subscale.

There is a significant difference in the originality sub-scale for the students in the experimental group. This may be related to the fact that while creating prototypes in STEM activities, the activity was directed towards producing structures that can provide the desired goals from the students (the fastest slide that reaches the ground from $a \mathrm{~cm}$ height or the slowest slide that will reach the ground from height of $b \mathrm{~cm}$ ) (Siew \& Ambo, 2020). Thus, students' creation of different designs to achieve the desired result and scoring these designs in terms of convenience and functionality shows that students developed their original thinking skills. In the implementation of the activities that drew on research-inquiry-based learning approach of the control group students, students were provided with a list of materials to be used while creating the model and that all groups made similar designs, this might be a reason why their original thinking skills may not have developed.

The analysis results for the SCT flexibility sub-scale shows that there is no significant difference between the pre-tests of the experimental-control groups; there is a significant difference in favour of the experimental group between the post-tests. At the same time, in the SCT flexibility sub-scale, there is a significant difference between the experimental group's pre-test and post-test flexibility scores in favour of the post-test; on the other hand, there is not a significant difference between the pre-test and post-test flexibility scores of the control group (Table 14). The success of the experimental group students in the flexibility sub-scale is due to the randomization of the groups in each of the STEM activities. In other words, students formed a group to make prototype and each of them developed a different perspective on design, it affected flexible thinking skills of students (Ceylan, 2014; Nurtanto, Pardjono, Widarto \& Ramdani, 2020). In addition, during the activities, students in the group did brainstorming which may have helped students to develop more than one perspective in the flexibility sub-scale of scientific creativity.

In the analysis results for SCT fluency sub-dimension, there is no significant difference in fluency scores between the pre-tests results of the experimental-control groups, while there is a 
significant difference between the post-tests in favour of the experimental group. According to the data of SCT fluency sub-scale, there is a statistically significant difference between the pre-test and post-test scores of the experimental group in favour of the post-test. There is not any difference between the pre-test and post-test fluency scores of the control group. The reason for the experimental group students 'success in this subscale is related with students' in-group task distribution and producing the appropriate prototype in the desired time during the activities. In this process, the students thought quickly, found more than one option for a solution, and made a collective decision on the most suitable option among these options. This inevitably had positive effects on students' development of fluent thinking ability (Jin-Ho et al., 2014).

\subsection{Recommendations}

At the onset of the activities, it is necessary for the students to decide on the materials and quantities, and also determine the time they need while performing the engineering design steps. In addition, a fixed additional time should be given to the groups in cases when the activity cannot be completed or developed. Therefore, it is recommended to keep the determined time long for the first activities, shorten the periods for the following activities and determine the final sufficient time.

Students should be allowed to form their groups in the first activities, and it is recommended that the groups should be determined and established by the researcher. Thus, reflecting the heterogeneity within the group and between the groups will increase each students' responsibility and the communication within the group. In this way, students will be respectful to each other. Also, researchers should not approach the students with group leadership feeling, they should encourage students to perform with a collaborative approach. It is suggested that group collectivity or collaboration criteria can be added in the evaluation form.

Acknowledgements. This resarch is a part of Master's thesis of the first author under the supervision of the second author.

\section{References}

Bakırc1, H. \& Kutlu, E. (2018). Determination of science teachers' views on STEM approach. Turkish Journal of Computer and Mathematics Education, 9(2), 367-389. https://doi.org/10.16949/turkbilmat.417939

Basham, J. D. \& Marino, M. T. (2013). Understanding STEM education and supporting students through universal design for learning. Journal of Teaching Exceptional Children, 45(4), 8-15. https://doi.org/10.1177/004005991304500401

Büyüköztürk, Ş. (2011). Sosyal bilimler için veri analizi el kitabı [Data analysis handbook for social sciences]. Ankara: Pegem Akademi Publishing.

Bybee, R. W. (2010). Advancing STEM education: A 2020 vision. Technology and Engineering Teacher, 70(1), 3035.

Ceylan, S. (2014). A study for preparing an instructional design based on science, technology, engineering and mathematics (STEM) approach on the topic of acids and bases at secondary school science course (Unpublished master thesis). Uludağ University, Turkey.

Chippetta, E. L. \& Adams, A. D. (2004). Inquiry-based instruction. The Science Teacher, 71(2), 46-50.

Christensen, L. B. (2004). Experimental methodology. Pearson Education.

Çelik, K. \& Çavaş, B. (2012). The effect of inquiry based learning method for the teaching for reproduction, growth and development in the living things unit on the students' academic achievements, science process skills and attitudes toward science and technology course. Journal Ege Education, 13(2), 50-75.

Demir, A. \& Çökelez, A. (2012, June). Investigation of the conceptual learning of $6^{\text {th }}$ grade students on the concepts of mass, weight and gravity. Paper presented at 10th National Science and Mathematics Education Congress. Niğde University, Turkey.

Dong-Ju, O., Jin-Ho, B. \& Su-Hong, P. (2016). The effects of science based enrichment STEAM gifted program on creative thinking activities and emotional intelligence of elementary science gifted students. Journal of Korean Elementary Science Education, 35(1), 13-25. https:// doi.org/10.15267/keses.2016.35.1.013 
Dumanoğlu, F. (2018). Effect of science, technology, engineering and mathematics activities on seventh grade students' academic achievement and attitudes (Unpublished master thesis). İstanbul University, Turkey.

Gazibeyoğlu, T. (2018). Investigation of the effect of stem applications on achievement in force and energy unit and attitudes towards science course of $7^{\text {th }}$ grade students (Unpublished master thesis). Kastamonu University, Turkey.

Genek, S. E., \& Küçük, Z. D. (2020). Investigation of scientific creativity levels of elementary school students who enrolled in a STEM program. Elementary Education Online, 19(3), 1715-1728. https://dx.doi.org/10.17051/ilkonline.2020.734849

Gökbayrak, S. \& Karışan, D. (2017). An investigation of the effects of STEM based activities on preservice science teacher's science process skills. Western Anatolia Journal of Educational Sciences, 8(2), 63-84.

Gülhan, F. \& Şahin, F. (2018). The effects of STEAM activities $7^{\text {th }}$ grade students' academic achievement, STEAM attitude and scientific creativities. Journal of Human Sciences, 15(3), 1675-1699.

Günbatar, M. S. \& Bakırc1, H. (2019). STEM teaching intention and computational thinking skills of preservice teachers. Education and Information Technologies, 24, 1615-1629. https://doi.org/10.1007/s10639018-9849-5

Havice, W. L. (2015). Integrative STEM education for children and our communities. The Technology Teacher, 75(1), 15-17.

Hu, W. \& Adey, P. (2002). A scientific creativity test for secondary school students. International Journal of Science Education, 24 (4), 389-403. https:/ / doi.org/10.1080/09500690110098912

International Technology Education Association (ITEA) (2007). Standards for technological literacy: content for the study of technology. www.iteaconnect.ora/TAA/PDFs/xstnd.pdf

Jin-Ho, B., Kum-Hyun, S., Bong-Hee, Y., Jin-Su, K., Guk-In, H., Sung-Gil, K., ...Hae-Jin, K. (2014). The effects of science lesson applying STEAM education on creative thought activities and emotional intelligence of elementary school students. Journal of Korean Elementary Science Education, 33(4), 762-772. https://doi.org/10.15267/keses.2014.33.4.762

Kara, Y. \& Şahin, B. (2019, April). Investigation of science teacher candidates' views on measurement and evaluation in STEM Education. Paper presented at the International Conference on Science, Mathematics, Entrepreneurship and Technology Education, İzmir/Turkey.

Kara, Y. (2018, October). Determination of the metaphors of science teacher candidates on STEM education. Paper presented at the 4th International Contemporary Educational Research Congress, Muğla, Turkey.

Karasar, N. (2003). Scientific research method. Ankara: Nobel Publishing

Karışan, D. \& Yurdakul, Y. (2017).The effects of microprocessors based science technology engineering and mathemetics (STEM) investigations on 6th grade students' attitudes towards these subject areas. Adnan Menderes University Faculty of Education Journal of Educational Sciences, 8(1), 37-52.

Keçeci, G. \& Kurbağ-Zengin, F. (2016). The effects of inquiry-based science teaching on students' science process skills and attitudes. International Journal of Social Science, 47, 269-287.

Kizılaslan, A. (2013). Chemistry education students' view on inquiry-based learning. The Journal of Academic Social Science, 1(1), 12-22.

Kim, D., Ko, D., Han, M. \& Hong, S. (2014). The effects of science lessons applying STEAM education program on the creativity and interest levels of elementary students. Journal of the Korean Association for Science Education, 34(1), 43-54. https://doi.org/10.14697/jkase.2014.34.1.1.00043

Koyunlu-Ünlü, Z. K. \& Dere, Z. (2018). Evaluation of STEM activities prepared by pre-school teacher candidates. Journal of Ahi Evran University Kırşehir Faculty of Education, 19(2), 1502-1512.

Lee, S. \& Lee, H. (2013). The effects of science lesson applying STEAM education on the creativity and science related attitudes of elementary school students. Journal of Korean Elementary Science Education, 32(1), 60-70. https://doi.org/10.15267/keses.2013.32.1.060

Lim, B. R. (2001). Guidelines for designing inquiry-based learning on the web: Online professional development of educators (Unpublished doctoral thesis). Indiana University, United States.

Ministry of National Education. (2018). Science curriculum. Ankara: State Books Printing House.

Minner, D. D., Levy, J. A. \& Century, J. (2010). Inquiry-based science instruction what is it and does it matter? Results from a research synthesis years 1984 to 2002. Journal of Research in Science Teaching, 47(4). 474-496. https:// doi.org/10.1002/tea.20347

National Research Council (NRC) (2002). Approaches to improve engineering design. Washington: The National Academic Press. 
Nurtanto, M., Pardjono, P., Widarto, W. \& Ramdani, S. D. (2020). The effect of STEM-EDP in professional learning on automotive engineering competence in vocational high school. Journal for the Education of Gifted Young Scientists, 8(2), 633-649. https://doi.org/10.17478/jegys.645047

Partnership for 21 $1^{\text {st }}$ Century Skills (2009). P21 framework definitions. http://ncete.org/flash/pdfs/Infusing\%20Engineering\%20Hynes

Patton, M. Q. (2005). Qualitative research. Encyclopedia of statistics in behavioral science.

Pekbay, C. (2017). Effects of science technology engineering and mathematics activities on middle school students (Unpublished doctoral dissertation). Hacettepe University, Turkey.

Pizzolato, N., Fazio, C. \& Battaglia, O. R. (2014). Open inquiry-based learning experiences: A case study in the context of energy exchange by thermal radiation. European Journal of Physics, 35(1), 1-16.

Ryu, J. \& Lee, K. (2013). The effects of brain-based STEAM teaching-learning program on creativity and emotional intelligence of the science-gifted elementary students and general students. The Korean Elementary Science Education Society, 32(1), 36-46. https://doi.org/10.15267/keses.2013.32.1.036

Sağdıç, M. \& Bakırcı, H. (2020). The effect of guided research inquiry teaching method on $7^{\text {th }}$ grade students' STEM attitudes. Afyon Kocatepe University Journal of Social Sciences, 22(2), 363-376. https://doi.org/10.32709/akusosbil.534626

Sağdıç, M., Bakırcı, H. \& Boynukara, Z. (2019). The effect of guided inquiry teaching model on the scientific process skills of students: the case study of force and energy unit. Yüzüncü Yal University Journal of Education Faculty, 16(1), 943-959. http://dx.doi.org/10.23891/efdyyu.2019.148

Samuels, K. ve Seymour, R. (2015). The middle school curriculum: Engineering anyone? Technology and Engineering Teacher, 74(6), 8-12.

Siew, N. M., \& Ambo, N. (2020). The scientific creativity of fifth graders in a STEM project-based cooperative learning approach. Problems of Education in the 21st Century, 78(4), 627-643. https://doi.org/10.33225/pec/20.78.627

Stylianidou, F., Ormerod, F. \& Ogborn, J. (2002). Analysis of science textbook pictures about energy and pupils readings of them. International Journal of Science Education, 24(3), 257-283. https://doi.org/10.1080/09500690110078905

Şahin, A., Ayar, M. C. \& Adıgüzel, T. (2014). STEM related after-school program activities and associated outcomes on student learning. Educational Sciences: Theory \& Practice, 14(1), 1-26. https://doi.org/10.12738/estp.2014.1.1876

Taşdemir, A. \& Demirbaş, M. (2010). The level of correlation of concepts that primary students seen topics in science and technology class with daily life. International Journal of Human Sciences, 7(1), 124-148.

Thier H. D., \& Davis, B. (2001). Developing inquiry-based science materials. A guide for educators. Teachers College Press.

Trna, J., Trnova, E. \& Sibor, J. (2012). Implementation of inquiry-based science education in science teacher training. Journal of Educational and Instructional Studies in the World, 2(4). 199-209.

Tunc, C., \& Bagceci, B. (2021). Teachers' views of the implementation of STEM approach in secondary schools and the effects on students. Pedagogical Research, 6(1), 2-11. https://doi.org/10.29333/pr/9295

Vogt, W. P., Gardner, D. C. \& Haeffele, L. M. (2012). When to use what research design. Guilford Press.

Wilder, M. \& Shuttleworth, P. (2005). Cell inquiry: A 5E learning cycle lesson, science activities: Classroom projects and curriculum ideas. Science Activities, 41(4). 37-43. https://doi.org/10.3200/SATS.41.4.37-43

Wood, W. B. (2003). Inquiry-based undergraduate teaching in life sciences at large research universities: A perspective on the boyer commission report. Cell Biology Education, 2, 112-116. https://doi.org/10.1187/cbe.03-02-0004

Yamak, H., Bulut, N. \& Dündar, S. (2014). The effect of STEM activities on $5^{\text {th }}$ grade students' scientific process skills and attitudes towards science. Gazi University Journal of Education, 34(2), 249-265.

Yasak, M. T. (2017). Applications of science, technology, engineering and mathematics in design based science education: Sample of the theme of pressure (Unpublished master thesis).Cumhuriyet University, Turkey.

Yürümezoğlu, K., Ayaz, S. \& Çökelez, A. (2009). Grade 7-9 students' perceptions of energy and related concepts. Necatibey Faculty of Education Electronic Journal of Science and Mathematics Education, 3(2), $52-73$. 
Appendix 1. Sample STEM Activity Used in the Study

Activity Name: Bridge Construction

Class Level: $7^{\text {th }}$ grade

Recommended duration: 4 lesson

Outcomes: F.7.3.1.1. The force of gravity acting on the mass names as weight.

\section{Problem Status}

In Van, people in village A cannot directly cross the opposite side due to the stream; they can go up to $10 \mathrm{~km}$ away from the village and cross from there. The villager reported this problem to the municipality. The municipality says they will give the construction work to the company that has made the most durable bridge construction. You are one of the construction companies dealing with bridges. Your goal is to make the most durable, as cheap as possible and aesthetically suitable bridge model. Marbles will be used to measure the durability of the model. Who will be the company that carries the most marbles, makes the bridge model as cheap and aesthetically beautiful as possible?

\section{Reasearch:}

Demolished or durable?

$\checkmark$ Groups designed bridges to measure their strength by drawing them on their worksheets.

$\checkmark$ They hypothesized about how many coins the bridges they built would carry.

$\checkmark$ Each group tested the bridges they designed and recorded the data they obtained.

$\checkmark$ Discussed the reasons for collapsing bridges. The main terms to be learned were introduced.

Force: The effect that stops a moving object, moves a stationary object, changes the shape, direction and direction of objects is called force.

Weight: The gravitational force exerted by gravity on the mass of an object is called weight.

Weight is a force, therefore one can mention about the weight applied by the coin.

Transmission of force in bridges: The forces are transmitted and dispersed from the upper part towards the lower parts, towards the piers of the bridge. It transfers the load collected in the centre to the shores and to the bridge piers.

Imagination: Students are encouraged to imagine the bridge that they would make. They brainstormed with their group mates about the durability, aesthetics and cheap bridge model making.

Planning: They decided as a group how to design the bridge that they imagined. They were expected to design and build model of the bridge. The materials are proportional to the number of groups (For example; there are 6 of the same material). The students took the needed materials from the teacher's desk. Individuals within the groups were assigned engineering tasks (Task sharing is done in the form of designing, constructing and testing the durability of the bridge). The students made sure that the predictions were established before starting the designs. As a result of the joint decision taken with the students, the length of the bridge model was $45 \mathrm{~cm}$.

In the planning process, the "Activity Evaluation Rubric", which gives criteria about how they will be evaluated, was presented to the students with an interactive whiteboard. 
Designing and building: Students started to build the bridge they designed.

Testing: When the designs of the groups were finished, they started testing the bridges. Marbles were used to test the durability of the bridge model.

Development: After the groups test the strength of their bridges, the students are asked to "What kind of changes would you make to the bridge in order to make your bridge more durable?" If students wanted to change or improve their structure, Extra time was given to them.

Communication: The groups explained their bridges to other groups. Meanwhile, the groups asked questions to each other about their designs. After the construction and testing was completed, the results were discussed.

$\checkmark$ Which group's bridge model is more durable?

$\checkmark$ Are the marbles added to the bridge considered as weight or mass?

$\checkmark$ Which type of bridge does your bridge model fit into?

$\checkmark$ What is the maximum number of marbles carried by the bridge?

\section{BRIDGE MODEL EVALUATION RUBRIC:}

Bridges of the groups are evaluated according to the rubric below. The group with the highest score became the winner of the competition.

\begin{tabular}{|l|l|l|l|}
\hline Categories & $\begin{array}{c}\text { Very good } \\
\text { (3 points) }\end{array}$ & $\begin{array}{c}\text { Good } \\
\text { (2 Points) }\end{array}$ & $\begin{array}{c}\text { Needs to be developed } \\
\text { (1 Point) }\end{array}$ \\
\hline 1-Group understands the problem. & & & \\
\hline 2-Group work is done very well & & & \\
\hline $\begin{array}{l}\text { 3-Design turn into an aesthetically } \\
\text { beautiful bridge. }\end{array}$ & & & \\
\hline $\begin{array}{l}\text { 4- Group made the model of the bridge } \\
\text { as cheaply as possible. }\end{array}$ & & & \\
\hline $\begin{array}{l}\text { 5- The bridge model made by the } \\
\text { groups is durable. }\end{array}$ & & & \\
\hline $\begin{array}{l}\text { 6-The draft drawing of the group is clear } \\
\text { and understandable. }\end{array}$ & & & \\
\hline $\begin{array}{l}\text { 7-The analysis of the group is clear and } \\
\text { understandable. }\end{array}$ & & & \\
\hline $\begin{array}{l}\text { 8-Students' estimates are compatible } \\
\text { with the estimation results. }\end{array}$ & & & \\
\hline
\end{tabular}

\section{Materials:}

The following materials will be left on the teacher's table as equal with the number of groups. Students will take the needed material from the table (They can use more than one of the same material. Calculation of the total fee will be made accordingly). The price of each material is listed under the student handout. At the end of the activity, the expenses made by the students for the bridge model will be calculated.

- Coloured cardboard

- Cardboard

- Scissor

- Hot Melt Silicone Gun

- Utility knife
- $\quad$ Glue $(90 \mathrm{ml}-60 \mathrm{ml})$

- Thread

- Silicone glue stick

- Marble

- Tape
- Paper Cup

- Pen/Pencil

- Ruler

- Marker 


\section{Pricing:}

Cardboard:5 TL, Silicone glue stick: 1 TL, Hot Melt Silicone Gun +1 Silicone glue stick: 30 TL, Coloured cardboard:3 TL, Ruler: 2TL, Scissor: 1 TL, Utility knife: 2 TL, Glue 90 ml: 3 TL, Glue 60 ml: 2 TL, Pen/Pencil: 2 TL, Marker: 3 TL Thread: $(1 \mathrm{~m}) 2$ TL- $(2 \mathrm{~m}) 3$ TL, Tape: 2 TL.

\section{PREPARATION:}

Students are divided into groups of 6 people.

$\checkmark$ Groups find a company name. 